\title{
A Shift from Work-Life Balance to Work- Life Choices: A Study on Tourism Professionals in Goa
}

Cheryl Venan Dias* and Venan Bonaventure Dias ${ }^{\dagger}$

\section{Abstract}

Work-life balance is passé, enter work-life choices. But the next question arises, is this concept applicable to every working individual? Goa is predominantly a tourist destination, which thrives on inbound tourism through its extensive dependency on chartered flights, EDM festivals and as a wedding destination. However this study focuses on career oriented men and women, as well as entrepreneurs who work for the tourism industry in Goa. Their focus is on providing travel solutions in terms of visa assistance, booking air travel, planning itineraries. In a nutshell their orientation is towards outbound travel. These individuals have also made some serious choices in life to achieve what they wanted in their professional front. The study tries to identify the human resource issues that are prevalent in the micro, small and medium enterprises that they work with. This also calls for defining the term small and medium tourism enterprises (SMTE). Issues may be translated into remuneration, ethical aspects, relocation, and working hours. The survey responses will reveal the work-life choices made in their business or career. The study also explores the identity perceptions of tourism professionals who enter the

\footnotetext{
* Assistant Professor, Department of Tourism and Heritage Management, DCT's S.S Dempo College of Commerce and Economics, Goa, India; thmdempo@gmail.com

† Research Associate, Antonio's Services, Goa, India
} 
business world. With the shift in insight of doing a job to being a career oriented individual or business person, we observe that the professionals also have a personal opinion on sense of responsibility, personal identity, and commitment. The study also delves into the aspect of choices related to achievement, mobility, self-worth, and work.

In the long run, we shape our lives, and we shape ourselves. The process never ends until we die. And the choices we make are ultimately our own responsibility.

-Eleanor Roosevelt

There's no such thing as work-life balance. There are work-life choices, and you make them, and they have consequences.

-Jack Welch

Keywords: Entrepreneurs, Identity perceptions, Work-life choices, Workaholism, Career choices, Work-life balance, Commitment.

\section{Introduction}

Defining Career Oriented Individual and Entrepreneur:

This exploratory study would like to identify the contemporary factors that influence a career oriented professional in the tourism industry. It tries to study the shift of concern from work-life balance to work-life choices; it also examines the preferences and motivations of high achievers, the type of job resources that make them committed to their career. It also explores the three types of commitment with a special focus on desire-based commitment. Though commitment to the family also requires commitment to work and thereby choices come to the forefront. Choice could relate to the question of who will stay back at home and take care of the dependent parents, or children. It could also mean could they travel and stay away from their families to study the client's nature of business or work in a foreign land. It could also imply their willingness to relocate and let us know that whether the family or spouse is supportive of such a move. It could also indicate developing oneself through further education or experience and getting better placed than their colleagues who would have been at 
the same career front in the past. Choice could even spell giving up a current position in order to start up a new enterprise on their own. Bernstein (2014) has quoted Judith and Ivor Martin's concept of identity as, "When attempting to enter the business world, you need to learn to be someone else. It is called having a professional identity". The concept is generalised to both genders. An entrepreneur has to project a different ego state during interaction with colleagues and subordinates. This process of projection has to be learnt and imbibed in due course of time.

\section{Literature Review}

A study (Roy and Andrews, 1999) highlights the process and outcome of persons who think and feel, it could be in a group or as an individual by the use of conscious awareness and choice to create human and environmental integration. The theoretical framework developed by Roy was termed as Adaptation and is extensively used and tested throughout this research.

In recent years the tourism industry both hospitality and travel have seen a tremendous increase in large multinational hotel, food and beverage and other tourism subsidiaries in the global scenario, the industry still thrives on large number of small and medium sized firms.(Baum, 1999; Lee-Ross, 1999; Piso, 1999).

This requires us to define small and medium tourism enterprises (SMTE's). According to a study (Breen, BerginSeers, Jago and Carlsen, 2005) SMTE's are all businesses, which operate in the tourism industry and employ up to hundred employees. These may include sole operators who do not employ any staff. They further define the concept of micro businesses, as those which employ between one and four workers, small businesses as those that employ between five and nineteen employees and medium businesses as ones which employ between twenty and hundred employees. 
The scope of this study ranges around study of micro, small, medium and large sized travel enterprises in Goa. Apart from this the HR aspect focuses on high standardisation and labour intensive feature of the industry. (Lashley and Taylor, 1998)

Tourism industry is well known for its high rate of attrition, as (Lucas, 1995) observed that this industry is characterised by high levels of attrition, which is particularly high amongst the front line and operational staff.

It is also evident that there are prevailing low standards with regards to small and medium enterprises due to lack of training and certification. However among all these there are men and women who strive to make the most of it, the biggest challenge faced by them are the work-life choices which will be discussed in this paper.

Powell (2009) and Thrane (2008) argued that the tourism industry considerably requires long work hours and lower than average pay.

Groysberg \& Abrahams (2014) highlighted some intriguing gender differences that emerged in their survey data; while defining professional success, women place more value than men do on individual achievement, having passion for their work, receive respect, and make a difference, but less value on organizational achievement and ongoing learning and development. Hence a lower percentage of women than men list financial achievement as an aspect of personal or professional success.

Due to the changing scenario there has been an entry of more women in the work force. A research that was done on worklife balance pertaining only to women has now shifted gears to both genders; it is no longer a woman related issue (Dash, Anand and Gangadharan 2012).

McClelland (1967) stated that strong 'inner urge', 'inner concern' and 'need for achievement' builds up the 38 
'achievement pressure' in people. This may make an individual to overlook the aspects of job demands and cling on to the available job resources to achieve the goals of becoming a leader or an entrepreneur. McClelland also suggested that it could be possible to induce achievement motivation in adults than place them in an un-induced environment.

Rai and Srivastava (2011) conducted an empirical study on a sample of 150 units run by women entrepreneurs. The findings indicated that they were motivated to start the enterprise because of profits and to make money, they did not want to work for others, they wanted control and freedom, the power to take their own decisions, and for the feeling of self-achievement. Some also wanted to provide employment opportunities to others.

In a company such as TATA Interactive Systems most of the senior management roles are taken up by both men and women who do not shy away from working long hours, which may work up to 12-14 hours at a stretch, just to provide optimum service and delivery to their clients. It also involves taking up calls from home, work from home option on weekends, in addition to working 9 to 5 in the office. Here the employees deliberately do not want to focus on work-lifebalance but more on work-life-choices; they choose to work and achieve more in life.

Another concept as proposed by a study (Kossek et al. 1998) is that Job Mobility Preparedness is the 'degree to which an individual prepares himself or herself to be ready to act on internal and external career opportunities'. This concept also explores the questions whether an individual is ready to be mobile, what could be the life circumstances that promotes this behaviour or prepares them for the next career move. 
The common behaviours suggested by Kossek et al., were actively looking out for new career opportunities within and outside the organisation, job market and profiles, they may seek to change the nature of their jobs, or align themselves to their own interest and strengths. Another study (Schyns et al., 2007) suggests that preparedness to change is an individual's wish to acquire higher task demands or greater complexity.

\section{Objectives of the Descriptive Research}

1. To profile the respondents business into their respective SMTE's.

2. To list the work-life choices made by travel professionals in Goa.

3. To study the differences in perception of professional choices made based on gender.

4. To highlight the influence of income group on mobility and work-life choices of travel professionals.

5. To identify the hierarchy of work-life choices of travel professionals in Goa.

\section{Research Design}

1. Exploratory and Descriptive research design has been used for this study

2. Quantitative and Qualitative research method

\section{Sample Size}

A sample size of $n=110$ travel professionals from North, and South has been taken for this exploratory research. Sampling method used was snow-ball sampling. A self-designed questionnaire was administered and was based on a five point Likert-scale the questions were based on aspects covered in the literature review.

\section{Statistical Tests Used}

1. t-test for identifying significant statistical differences of choices between genders.

2. Cross tabulation to study the mobility choices of travel professionals based on income groups. 
3. Factor Analysis to identify the hierarchy of professional work-life choices.

4. Chi-square test on work-life choices made and income group.

\section{Data Analysis:}

Table 1: Profiling of the respondents travel agencies.

\begin{tabular}{|c|c|c|c|c|c|}
\hline & & $\vec{\Xi}$ & 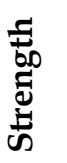 & 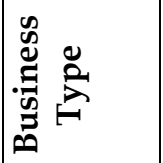 & 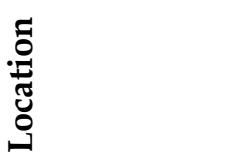 \\
\hline & Air Asia PSA & 1 & 2 & Micro & Panjim \\
\hline & Airsonic & 4 & 7 & Small & Panjim \\
\hline & Akbar Travel & 5 & 5 & Small & Panjim \\
\hline & Alpha Travel & 1 & 1 & Micro & Panjim \\
\hline & C\&K & 2 & 10 & Small & Panjim \\
\hline & Cicerone Air & 5 & 5 & Small & Margao \\
\hline & Cozy Nook & 6 & 6 & Small & Panjim \\
\hline & DGRD Tours & 1 & 4 & Micro & Panjim \\
\hline$\Xi$ & EzyTravels & 2 & 5 & Small & Panjim \\
\hline : & Freedom & 12 & 19 & Medium & Panjim / Vasco \\
\hline$\stackrel{\infty}{\rightrightarrows}$ & Goa Shipping Ltd & 1 & 1 & Micro & Vasco \\
\hline ప్ర & Deepti Travels & 1 & 1 & Micro & Calangute \\
\hline & Mahalasa Ent. & 8 & 8 & Small & Vasco \\
\hline & PriNati & 3 & 4 & Micro & Panjim \\
\hline & Riya Travels & 13 & 18 & Small & Panjim \\
\hline & Splendor T\&T & 3 & 4 & Micro & Panjim \\
\hline & Thomas Cook & 10 & 10 & Small & Panjim \\
\hline & Trade Wings & 3 & 10 & Small & Panjim \\
\hline & Travel Pack & 21 & 200 & Large & Verna \\
\hline & Vikas Ent. & 1 & 1 & Micro & Vasco \\
\hline & Vincent Travels & 7 & 8 & Small & Vasco \\
\hline & Responses & $\mathrm{n}=110$ & - & - & - \\
\hline
\end{tabular}

Source: Venan Bonaventure Dias

From the responses received from the 21 travel agencies. The table 1 indicates that 8 agencies are classified under Micro Organisations, 11 are Small agencies, 1 medium and 1 large organisation. 
Table 2: Reliability of the instrument

\begin{tabular}{|c|c|}
\hline \multicolumn{2}{|c|}{ Reliability Statistics } \\
\hline Cronbach's Alpha & N of Items \\
\hline .735 & 15 \\
\hline
\end{tabular}

Source: Venan Bona venture Dias

The Cronbach's Alpha score of $73.5 \%$ on the 15 items that were presented in the survey indicates that the instrument is highly reliable.

Table 3: Demographics

\begin{tabular}{|c|c|c|c|c|c|}
\hline \multicolumn{2}{|r|}{ Variables } & \multicolumn{3}{|c|}{ Frequency of Respondents } & \multirow{2}{*}{$\begin{array}{r}\text { Percentage } \\
100 \%\end{array}$} \\
\hline & & $\begin{array}{c}\text { Male } \mathrm{n} \\
=49\end{array}$ & $\begin{array}{c}\text { Female } \\
n=61\end{array}$ & \begin{tabular}{|c|} 
Total \\
$\mathrm{N}=110$
\end{tabular} & \\
\hline \multirow{5}{*}{$\underbrace{\infty}_{\pi}$} & $<25$ & 10 & 17 & 27 & $24.5 \%$ \\
\hline & $26-30$ & 14 & 29 & 43 & $39.09 \%$ \\
\hline & $31-40$ & 15 & 11 & 26 & $23.63 \%$ \\
\hline & $41-50$ & 9 & 2 & 11 & $10 \%$ \\
\hline & $>50$ & 1 & 2 & 3 & $2 \%$ \\
\hline \multirow{6}{*}{ 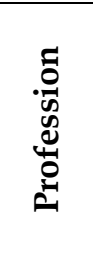 } & Employed & 43 & 57 & 100 & $90.90 \%$ \\
\hline & Self Employed & 6 & 4 & 10 & $9.10 \%$ \\
\hline & House Wife & 0 & 0 & 0 & 0 \\
\hline & Retired & 0 & 0 & 0 & 0 \\
\hline & Entrepreneur & 0 & 0 & 0 & 0 \\
\hline & Others & 0 & 0 & 0 & 0 \\
\hline \multirow{4}{*}{ 坣 } & Single & 26 & 29 & 55 & $50 \%$ \\
\hline & Married & 23 & 30 & 53 & $48.18 \%$ \\
\hline & Single Parent & 0 & 2 & 2 & $1.81 \%$ \\
\hline & Others & 0 & 0 & 0 & 0 \\
\hline \multirow{4}{*}{ 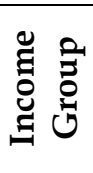 } & 50,000 - 1Lakh & 17 & 32 & 49 & $44.54 \%$ \\
\hline & Above 1Lakh - 3Lakhs & 21 & 25 & 46 & $41.81 \%$ \\
\hline & Above 3Lakhs - 5Lakhs & 7 & 2 & 9 & $8.18 \%$ \\
\hline & Above 5 Lakhs & 4 & 2 & 6 & $5.45 \%$ \\
\hline
\end{tabular}

Source: Cheryl Venan Dias

From table 3 it is indicated that though number of the female employees working at a travel enterprise is higher than males, on the other hand males belong to a higher income group than females. 
Table 4: List of choices made by travel professionals in Goa

\begin{tabular}{|l|c|}
\hline \multicolumn{1}{|c|}{ Professional Choices } & Mean \\
\hline Professional Identity Choice & 3.90 \\
\hline Self-Worth Choice & 3.72 \\
\hline Achievement Based Choice & 3.69 \\
\hline Mobility Choice & 3.56 \\
\hline Work Life Choice & 3.45 \\
\hline
\end{tabular}

Source: Cheryl Venan Dias

With reference to list of choices made by travel professionals in Goa, table 4 indicates the mean scores of all professional choices made in a descending order.

\section{Perceptions of travel professionals working in Goa}

Hypothesis statement: H1: There will be a significant difference in work-life choices made among the genders.

\section{Variables under test}

Independent Variable: Choices Made

Dependent Variable: Perception among the genders

$\mathrm{H}_{01}$ : There is no difference in the perception of professional choices between genders.

Table 5: t-test for variables tested

\begin{tabular}{|c|c|c|c|c|}
\hline Variable & Mean Diff. & Std.Error & t-value & Significance \\
\hline \multicolumn{5}{|c|}{ Professional Identity Choice* } \\
\hline PIC 1 & 0.101 & 0.150 & 0.697 & 0.486 \\
\hline PIC 2 & 0.148 & 0.147 & 1.008 & 0.315 \\
\hline PIC 3 & 0.123 & 0.201 & 0.614 & 0.540 \\
\hline \multicolumn{5}{|c|}{ Mobility Choice* } \\
\hline MC1 & -0.158 & 0.198 & -0.797 & 0.426 \\
\hline MC2 & -0.023 & 0.220 & -0.104 & 0.916 \\
\hline MC3 & -0.148 & 0.236 & -0.627 & 0.531 \\
\hline \multicolumn{5}{|c|}{ Achievement Based Choice* } \\
\hline $\mathrm{AC} 1$ & -0.077 & 0.166 & -0.464 & 0.642 \\
\hline $\mathrm{AC} 2$ & 0.248 & 0.161 & 1.532 & 0.128 \\
\hline AC3 & 0.082 & 0.180 & 0.456 & 0.648 \\
\hline \multicolumn{5}{|c|}{ Self-Worth Choice* } \\
\hline SWC1 & 0.001 & 0.171 & 0.005 & 0.995 \\
\hline
\end{tabular}




\begin{tabular}{|l|l|l|l|l|}
\hline SWC2 & 0.086 & 0.167 & 0.514 & 0.607 \\
\hline SWC3 & -0.255 & 0.211 & -1.206 & 0.230 \\
\hline \multicolumn{5}{|c|}{ Work Life Choice* } \\
\hline WLC1 & 0.308 & 0.189 & 1.633 & 0.105 \\
\hline WLC2 & 0.435 & 0.184 & 2.357 & $0.020^{* *}$ \\
\hline WLC3 & -0.168 & 0.198 & -0.853 & 0.395 \\
\hline
\end{tabular}

Source: Venan Bonaventure Dias and Cheryl Venan Dias

Table 5 indicates that perception towards work-life choice related to working long hours has a significant difference among genders leading to rejecting the null hypothesis and accepting the alternative hypothesis that there is a significant difference among perceptions of genders with regards to working long hours. While for all other variables the null hypothesis is accepted.

Table 6: Cross Tabulation between choices to relocate based on better remuneration and current income status.

\begin{tabular}{|c|c|c|c|c|c|c|}
\hline & \multicolumn{4}{|c|}{ Income Group } & \multirow[b]{2}{*}{ Total } \\
\hline & & $\begin{array}{c}50,000- \\
1 \text { Lakh }\end{array}$ & $\begin{array}{c}\text { Above } \\
1 \text { Lakh - } 3 \\
\text { Lakhs }\end{array}$ & $\begin{array}{c}\text { Above } \\
3 \text { Lakhs - } \\
5 \text { Lakhs }\end{array}$ & $\begin{array}{c}\text { Above } \\
5 \text { Lakhs }\end{array}$ & \\
\hline \multirow{5}{*}{$\begin{array}{l}\text { I am willing } \\
\text { to relocate } \\
\text { for a better } \\
\text { remuneratio } \\
\text { n or pay } \\
\text { package }\end{array}$} & $\begin{array}{l}\text { Strongly } \\
\text { Disagree }\end{array}$ & 2 & 2 & 1 & 0 & 5 \\
\hline & Disagree & 2 & 1 & 0 & 2 & 5 \\
\hline & Neutral & 10 & 16 & 1 & 1 & 28 \\
\hline & Agree & 18 & 18 & 6 & 1 & 43 \\
\hline & $\begin{array}{l}\text { Strongly } \\
\text { Agree }\end{array}$ & 17 & 9 & 1 & 2 & 29 \\
\hline \multicolumn{2}{|l|}{ Total } & 49 & 46 & 9 & 6 & 110 \\
\hline
\end{tabular}

Source: Venan Bonaventure Dias

Table 6 indicates that travel professionals in all the income groups are willing to relocate based on better remuneration.

$\ddagger *$ Elaborated in table $9 \mathrm{~b}$ for Factor Analysis. ** Significant at two-tailed $\mathrm{p}<0.05$ 
Table 7: Cross tabulation between choice to work in any other part of India and the income group.

\begin{tabular}{|c|c|c|c|c|c|c|}
\hline & \multicolumn{4}{|c|}{ Income Group } & \multirow[t]{2}{*}{ Total } \\
\hline & & $\begin{array}{c}50,000- \\
1 \text { Lakh }\end{array}$ & $\begin{array}{l}\text { Above } \\
1 \text { Lakh } \\
3 \text { Lakhs }\end{array}$ & $\begin{array}{c}\text { Above } \\
3 \text { Lakhs } \\
5 \text { Lakhs }\end{array}$ & $\begin{array}{l}\text { Above } \\
5 \text { Lakhs }\end{array}$ & \\
\hline \multirow{5}{*}{$\begin{array}{l}\text { I cannot } \\
\text { work in } \\
\text { any other } \\
\text { part of } \\
\text { India as I } \\
\text { have a lot } \\
\text { at stake in } \\
\text { Goa. }\end{array}$} & $\begin{array}{l}\text { Strongly } \\
\text { Disagree }\end{array}$ & 4 & 3 & 1 & 1 & 9 \\
\hline & Disagree & 12 & 10 & 3 & 0 & 25 \\
\hline & Neutral & 11 & 10 & 2 & 3 & 26 \\
\hline & Agree & 13 & 14 & 2 & 1 & 30 \\
\hline & $\begin{array}{l}\text { Strongly } \\
\text { Agree }\end{array}$ & 9 & 9 & 1 & 1 & 20 \\
\hline \multicolumn{2}{|l|}{ Total } & 49 & 46 & 9 & 6 & 110 \\
\hline
\end{tabular}

Source: Venan Bonaventure Dias

Table 7 displays a distribution of travel professionals who are willing to work in other parts of India as well as in Goa;50 do feel that they cannot relocate to other parts of India as they have a lot at stake in Goa.

Table 8 Cross Tabulation between choice to work only in Goa than any other part of the world and income group.

\begin{tabular}{|c|c|c|c|c|c|c|}
\hline & \multicolumn{4}{|c|}{ Income Group } & \multirow[t]{2}{*}{ Total } \\
\hline & & $\begin{array}{c}50,000- \\
1 \text { Lakh }\end{array}$ & $\begin{array}{c}\text { Above } \\
1 \text { Lakh - } \\
3 \text { Lakhs }\end{array}$ & $\begin{array}{c}\text { Above } \\
3 \text { Lakhs - } \\
5 \text { Lakhs }\end{array}$ & \begin{tabular}{|c|} 
Above \\
5 Lakhs
\end{tabular} & \\
\hline \multirow{5}{*}{$\begin{array}{l}\text { I prefer to } \\
\text { work in } \\
\text { Goa than in } \\
\text { any other } \\
\text { part of the } \\
\text { world. }\end{array}$} & $\begin{array}{l}\text { Strongly } \\
\text { Disagree }\end{array}$ & 4 & 2 & 0 & 0 & 6 \\
\hline & Disagree & 5 & 2 & 3 & 0 & 10 \\
\hline & Neutral & 13 & 14 & 3 & 2 & 32 \\
\hline & Agree & 11 & 15 & 3 & 2 & 31 \\
\hline & $\begin{array}{l}\text { Strongly } \\
\text { Agree }\end{array}$ & 16 & 13 & 0 & 2 & 31 \\
\hline \multicolumn{2}{|l|}{ Total } & 49 & 46 & 9 & 6 & 110 \\
\hline
\end{tabular}

Source: Venan Bonaventure Dias

Table 8 indicates that 62 travel professionals are willing to work only in Goa than in any other part of the world. 
The mobility based choices indicates that though better remuneration is something that the travel professionals may consider to move to another state or agency, however they prefer to work in Goa than in any other part of the world as they have a lot at stake in Goa.

\section{Factor Analysis to identify the hierarchy of professional work life choices.}

Table 9 a: KMO and Bartlett's Test

\begin{tabular}{|l|l|r|}
\hline \multicolumn{2}{|c|}{ Kaiser-Meyer-Olkin Measure of Sampling Adequacy. } & .723 \\
\hline \multirow{3}{*}{ Bartlett's Test of Sphericity } & Approx. Chi-Square & 317.012 \\
\cline { 2 - 3 } & df & 105 \\
\cline { 2 - 3 } & Sig. & .000 \\
\hline
\end{tabular}

Table 9 b: Rotated Component Matrix ${ }^{a}$

\begin{tabular}{|l|c|c|c|c|c|}
\hline & \multicolumn{4}{|c|}{ Component } \\
\cline { 2 - 6 } & 1 & 2 & 3 & 4 & 5 \\
\hline $\begin{array}{l}\text { I strongly want to make a } \\
\text { positive change in society. } \\
\text { (PIC 1) }\end{array}$ & .180 & -.027 & .825 & .159 & .193 \\
\hline $\begin{array}{l}\text { I am willing to relocate for a } \\
\text { better remuneration or pay } \\
\text { package. (MC1) }\end{array}$ & .108 & -.027 & .043 & -.245 & .682 \\
\hline $\begin{array}{l}\text { While at work do you feel a } \\
\text { strong inner urge for } \\
\text { achievement .(AC1) }\end{array}$ & .593 & .172 & .344 & -.151 & .193 \\
\hline $\begin{array}{l}\text { I prefer to work in Goa than in } \\
\text { any other part of the } \\
\text { world.(MC2) }\end{array}$ & .033 & .219 & .015 & .622 & -.268 \\
\hline $\begin{array}{l}\text { I can largely determine what } \\
\text { matters the most for my } \\
\text { organisation. (PIC 2) }\end{array}$ & .578 & .306 & .012 & -.181 & -.439 \\
\hline $\begin{array}{l}\text { Do you feel you are } \\
\text { adequately empowered to do } \\
\text { more than what your role } \\
\text { entails? (SWC1) }\end{array}$ & -.091 & .197 & .480 & -.005 & -.395 \\
\hline $\begin{array}{l}\text { Do you have the willingness } \\
\text { to take business risks or work } \\
\text { related risks? (WLC1) }\end{array}$ & .225 & .626 & .240 & .016 & -.078 \\
\hline
\end{tabular}




\begin{tabular}{|l|c|c|c|c|c|}
\hline & \multicolumn{5}{|c|}{ Component } \\
\cline { 2 - 6 } & 1 & 2 & 3 & 4 & 5 \\
\hline $\begin{array}{l}\text { Do you feel motivated by the } \\
\text { thought that your business can } \\
\text { generate employment for } \\
\text { others? (SWC2) }\end{array}$ & .437 & .204 & .561 & -.100 & -.266 \\
\hline $\begin{array}{l}\text { I cannot work in any other } \\
\text { part of India as I have a lot at } \\
\text { stake in Goa.(MC3) }\end{array}$ & .118 & -.101 & .091 & .853 & .037 \\
\hline $\begin{array}{l}\text { Do you feel you can work long } \\
\text { hours if the job } \\
\text { demands?(WLC2) }\end{array}$ & .498 & .345 & .076 & .118 & .116 \\
\hline $\begin{array}{l}\text { Do you feel that you can speak } \\
\text { up againstthings that are } \\
\text { unethical or not in line with } \\
\text { your principles?(SWC3) }\end{array}$ & .784 & -.019 & .061 & .207 & .047 \\
\hline $\begin{array}{l}\text { Have you developed a control } \\
\text { system in your organisation to } \\
\text { stream line a process? (AC2) }\end{array}$ & .184 & .605 & .062 & -.117 & -.270 \\
\hline $\begin{array}{l}\text { Have you contributed any } \\
\text { innovative ideas within your } \\
\text { organisation? (AC3) }\end{array}$ & .030 & .570 & .584 & .073 & .035 \\
\hline $\begin{array}{l}\text { The course of my career } \\
\text { largely depends on me.(PIC3) }\end{array}$ & .453 & .450 & -.026 & .224 & .007 \\
\hline $\begin{array}{l}\text { Do you feel it necessary to } \\
\text { bend rules or compromise to } \\
\text { complete a task. (WLC3) }\end{array}$ & .008 & .576 & .004 & .371 & .459 \\
\hline
\end{tabular}

The KMO measure indicates a satisfactory adequacy level of 0.723 , validating the analysis indicated in table 9a. While table 9b displayed the analysis which yielded five factors. The first factor comprised of the variables AC1, PIC2, WLC2,SWC3, PIC3 indicates that variables related to achievement, self-worth, and work life choices take precedence over Second Factor which comprised of WLC1, AC2, and WLC3. The third factor comprised of AC3, PIC1 and SWC2. The fourth factor comprised of MC2 and $\mathrm{MC} 3$, the fifth factor comprised of MC1 which indicated that mobility based choices are of least priority to the travel professionals in Goa. Together the five factors explained $58.229 \%$ of the overall variation (See Appendix 1) Table 10: Professional Choices - Dichotomous Response 
Table 10: Professional Choices - Dichotomous Response

\begin{tabular}{|l|c|c|c|}
\hline \multicolumn{4}{|c|}{ Choices made while seeking employment } \\
\hline & Observed N & Expected N & Residual \\
\hline Yes & 25 & 55.0 & -30.0 \\
\hline No & 85 & 55.0 & 30.0 \\
\hline Total & 110 & & \\
\hline
\end{tabular}

Source: Venan Bonaventure Dias

Table 11: Chi-square test on choices made

\begin{tabular}{|c|c|}
\hline \multicolumn{2}{|r|}{ Test Statistics } \\
\hline & Choices made while seeking employment \\
\hline Chi-Square & 32.727 \\
\hline Df & 1 \\
\hline Asymp. Sig. & .000 \\
\hline $\begin{array}{l}\text { a. } 0 \text { cells } \\
\text { minimum ex }\end{array}$ & $\begin{array}{l}\text { ave expected frequencies less than } 5 \text {. The } \\
\text { ell frequency is } 8.0 \text {. }\end{array}$ \\
\hline
\end{tabular}

Source: Venan Bonaventure Dias

As per table 11, there is a significant difference of the choices made by travel professionals, while seeking employment, where $p<0.05$ with $p=0.000$.

\section{Findings and Discussion}

While some attempt has been made to identify the professional identity through qualitative methods, a more concrete study can be made by mapping the transactional style inventory of the travel professionals in Goa. It is observed that though better remuneration could be a reason for relocation among the travel professionals, however they have a lot at stake in Goa including the choice to work only in Goa as compared to other parts of India. It was also observed that the travel professionals did make choices while seeking employment in this industry. There was a strong inner urge for achievement, they valued their professional identity, felt a sense of pride that their business was generating income for others; they were also willing to put in long hours of work if required. This opinion has significant differences while compared among both the genders. Some of the respondents have indicated 
growth and a better package abroad as a reason for a choice to relocate elsewhere. While others feel happy to be working for up to three years with the same organization, some have changed their professional orientation. Working also gives them a sense of responsibility. Some have taken over a family business even when there was a choice to move abroad. Discussion with travel industry professionals from other states revealed that poaching was quite rampant in states such as Karnataka and measures such as antipoaching and non-disclosure agreement does very little to curb this menace. The employees are more stable and loyal to their employer in Goa as qualitative data indicates that they have been with their employer between 3 to 20 years at a stretch, which is quite significant, in terms of loyalty. Factors related to achievement, selfworth, personal identity, work life choices appeared to be more significant than variables related to relocation; this also corresponds with the mean rank of choices made by the travel professionals.

\section{Conclusion}

Considering Goa to be unique in its entire splendour related to tourism, the travel professionals when given an option would prefer to make their career in Goa with more vigour and enthusiasm provided they are motivated.

As a part of theory building process Roy's adaptation model presents an individual as an holistic adaptive system which is subject to external stimulus, in this research the stimulus is working hours, pay scales, ethical dealing which will translate itself into self-worth, life goals, professional identity and other work-life choices.

There is an array of work-life choices made by the travel professionals. Some choices are intrinsic such as professional identity, self-worth, and achievement. Mobility based choices are based on extrinsic factors as in better remuneration and other commitments. There could also be other factors which are yet to be explored. It is also important that their skill levels be developed in order to add to the Human Capital requirement for the tourism sector in Goa. It is indicative while profiling the travel agencies that 
they are predominantly from the small and medium enterprises, who have budget constraints. This explains why many of the work force, i.e. $77 \%$ of male respondents and $93 \%$ of the female work force are in the salary range of 50,000 - 2 Lakhs per annum. Though they may enjoy the benefit of not being taxed, the cost of living and living standards may be affected due to this income range. This to some extent may be relaxed by the incentives offered by the service providers. It is also important to find out if there is a deferred incentive plan provided by the employers as in Public Provident fund and insurance, and Employee State Insurance Scheme or if the airlines and hospitality industry provides them with incentives in terms of familiarisation trips, free accommodation at a resort, new destination launch party, vouchers for sales of tickets and hotels, best performer awards, and to find out if they choose to work with micro, small and medium enterprises that offer such deferred incentive plans. All these aspects could be taken into consideration in a further study.

\section{Appendix 1}

\begin{tabular}{|c|c|c|c|c|c|c|c|c|c|}
\hline \multicolumn{10}{|c|}{ Total Variance Explained } \\
\hline \multirow[b]{2}{*}{ 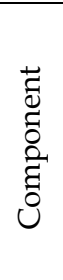 } & \multicolumn{3}{|c|}{ Initial Eigen values } & \multicolumn{3}{|c|}{$\begin{array}{l}\text { Extraction Sums of } \\
\text { Squared Loadings }\end{array}$} & \multicolumn{3}{|c|}{$\begin{array}{l}\text { Rotation Sums of } \\
\text { Squared Loadings }\end{array}$} \\
\hline & $\begin{array}{l}\text { ]ేँ } \\
\stackrel{0}{0}\end{array}$ & 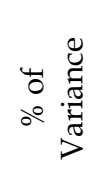 & 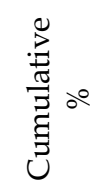 & 즁 & 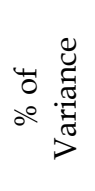 & 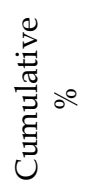 & 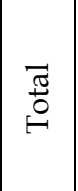 & 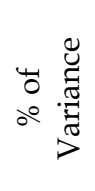 & 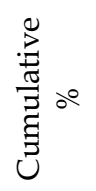 \\
\hline 1 & 3.717 & 24.778 & 24.778 & 3.717 & 24.778 & 24.778 & 2.099 & 13.992 & 13.992 \\
\hline 2 & 1.499 & 9.993 & 34.771 & 1.499 & 9.993 & 34.771 & 2.000 & 13.331 & 27.323 \\
\hline 3 & 1.335 & 8.899 & 43.671 & 1.335 & 8.899 & 43.671 & 1.769 & 11.790 & 39.113 \\
\hline 4 & 1.178 & 7.855 & 51.525 & 1.178 & 7.855 & 51.525 & 1.528 & 10.188 & 49.301 \\
\hline 5 & 1.006 & 6.704 & 58.229 & 1.006 & 6.704 & 58.229 & 1.339 & 8.927 & 58.229 \\
\hline 6 & .948 & 6.319 & 64.548 & & & & & & \\
\hline 7 & .844 & 5.627 & 70.175 & & & & & & \\
\hline 8 & .817 & 5.449 & 75.624 & & & & & & \\
\hline 9 & .729 & 4.858 & 80.482 & & & & & & \\
\hline 10 & .638 & 4.251 & 84.734 & & & & & & \\
\hline 11 & .617 & 4.111 & 88.845 & & & & & & \\
\hline 12 & .535 & 3.567 & 92.412 & & & & & & \\
\hline 13 & .468 & 3.119 & 95.530 & & & & & & \\
\hline 14 & .354 & 2.362 & 97.893 & & & & & & \\
\hline 15 & .316 & 2.107 & 100.000 & & & & & & \\
\hline
\end{tabular}




\section{References}

Baum, T. (1995). Managing human resources in the European tourism and hospitality industry: A strategic approach. London: Chapman and Hill.

Baum, T. (1999). Human resource management in tourism's small business sector: Policy dimensions. In D. Lee-Ross (Ed.) HRM in tourism and hospitality: International perspectives on small to medium sized enterprises. 3 -16. London: Cassell.

Bernstein, A. (April, 2014). "Behave Yourself". Harvard Business Review, 123.

Breen, J., Bergin-Seers, S., Jago, L., \& Carlsen, J. (2005). Small and Medium Tourism Enterprises: The Identification of Good Practice. Australia.

Dash, M., Anand, V., \& Gangadharan, A. (2012). "Perceptions of work-life balance among IT professionals". The IUP Journal of Organisational Behaviour, XI (1), 51-52.

Groysberg, B., \& Abrahams, R. (2014). Career planning: Manage your work manage your life. Harvard Business Review. 57

Janes, Patty.\& Wisnom, Mary. (2010) Changes in Tourism Industry Quality of Work Life Practices, Journal of Tourism Insights: 1(1), Article 13.

Kossek, E.E., Roberts, K., Fisher, S., \& Demarr, B. (1998). Career Self Management: A Quasi Experimental Assessment of the Effects of a Training Intervention. Personnel Psychology, 51 (4), 935-962.

Lashley, C., \& Taylor, S. (1998). Hospitality retail operations types and styles in the management of human resources, Journal of Retailing and Consumer Services, 5(3), 153-165.

Lee-Ross, D. (1999). Introduction. In D. Lee-Ross, (Ed.), HRM in tourism and hospitality international perspectives on small to medium sized enterprises (pp. XIII-XIX).London: Cassell.

Liz, D. (2004). Work-Life Balance Initiatives: Implication for Women. Employee Relations, 26 (4), 433-452.

Lucas, R. (1995). Managing employee relations in the hotel and catering industry. London: Cassell. 
McClelland, D. C. (1967). The Achieving Society, p.43 The Free Press New York.

Meyer, J.P., \& Allen, N. J. (1990). A Three-Component Conceptualization of Organisational Commitment. Human Resources Management Review, 4, 61-89.

Mink, M., Williams, P., \& Williams, R. (2003). How to be like women of influence. Westland Books. Pvt. Ltd., Chennai.

Patnaik, S. (2014). "Kneading her way to the starts". B \& C Magazine for Business and Consumers, Navhind Times. 4.

Piso, A. (1999). Hotel and catering workers: Class and Unionization. Employee Relations, 21(1), 176 - 188.

Powell, V. (2009). What effect do formalized human resource procedures have on employee motivation in the hospitality industry? Master's Thesis. University of Chester, England.

Rai, U.K., \& Srivastava, M. (2011). Aspirations and motives of women entrepreneurs: an empirical study of Varanasi district. The IUP Journal of Entrepreneurship Development, VIII (2), 23-33.

Roosevelt, E. (1939). Retrieved on 10 April 2014 from http://www.brainyquote.com/quotes/keywords/choices.html \#Aqf52Xo6qZ2TEYZy.99

Roy, Sr. C., \& Andrews, H.A.(1999). The Roy adaptation model (2nd Ed.) Stamford, CT: Appleton \& Lange.

Schaufeli, W., \& Bakker, A. B. (2004). Job demands, job resources and the relationship with burnout and engagement: A Multi Sample Study. Journal of Organizational Behaviour, 25, 293-315.

Schyns, B., Torka, N., \& Gossling, T. (2007). Turnover intention and preparedness for change: Exploring leader-member exchange and occupational self efficacy as antecedents of two employability predicators. Career Development International, 12, (7), 660-679.

Thrane, C. (2008). Earnings differentiation in the tourism industry: Gender, human capital and socio-demographic effects. Tourism Management, 29(3), 514-524. 